\title{
Hydrolysis of trans-Tetramethrin in Buffered Aqueous Solutions
}

\author{
Toshiyuki Katagi \\ Environmental Health Science Laboratory, Sumitomo Chemical Co., Ltd., \\ Takatsukasa, Takarazuka 665, Japan
}

(Received February 23, 1993; Accepted May 17, 1993)

\begin{abstract}
Hydrolysis of a pyrethroid insecticide trans-tetramethrin (I) [3,4,5,6-tetrahydrophthalimidomethyl $(1 R S)$-trans-chrysanthemate] was examined at $25 \pm 1{ }^{\circ} \mathrm{C}$, using the ${ }^{14} \mathrm{C}$ preparations labeled at 1-position of the cyclopropyl ring or at 1- and 2-positions of the 3,4,5,6-tetrahydrophthalimido moiety. HPLC analysis of the buffered aqueous solutions showed that $\mathbf{I}$ was degraded following pseudo-first-order kinetics at $\mathrm{pH} 5.0$ with a rate of $4.08-4.99 \times 10^{-7}$ $\mathrm{sec}^{-1}$, while it was rapidly hydrolyzed with initial rates of $7.82-8.75 \times 10^{-6} \mathrm{sec}^{-1}$ at $\mathrm{pH} 7$ and $6.02-8.62 \times 10^{-4} \mathrm{sec}^{-1}$ at $\mathrm{pH} 9$, followed by slower hydrolysis. HPLC and TLC cochromatographies with synthetic standards and LC-MS analysis showed that I was primarily hydrolyzed to the unstable tetrahydrophthalamic acid derivative of $\mathbf{I}$ via opening of the cyclic imido moiety. The ester linkage was subsequently cleaved to form trans-chrysanthemic acid and the unstable $N$-hydroxymethyl 3,4,5,6-tetrahydrophthalamic acid. The latter amic acid was stepwisely hydrolyzed by liberating formaldehyde to 3,4,5,6-tetrahydrophthalic acid via its amide derivative.
\end{abstract}

\section{INTRODUCTION}

Tetramethrin (Neo-Pynamin) is a synthetic pyrethroid characterized by its high knockdown and flushing-out activities ${ }^{1)}$ and the $d$ trans-isomer is known to be most potent. ${ }^{2}$ The metabolic studies of tetramethrin have revealed that ester cleavage and/or oxidation are the main degradation pathways in mammals, ${ }^{3,4}$ and a role of glutathione conjugation has been discussed in relation to its metabolism. ${ }^{5)}$ Since tetramethrin has a photo-labile chrysanthemic acid moiety, a variety of photoreactions are considered to proceed similarly as in other synthetic pyrethroids. ${ }^{6)}$ The rapid photodegradation via isomerization, epoxidation and/or hydroxylation as well as ester cleavage has been previously reported in organic solvents. ${ }^{7,8)}$ For an environmental safety, hydrolysis of tetramethrin in aqueous phase should be first investigated but such information has not been available. Although the gas chromatographic analysis after the alkaline hydrolysis has been reported for tetramethrin, ${ }^{9)}$ only chrysanthemic acid has been detected as a hydrolysis product.

This paper deals with hydrolysis of $\mathbf{I}$, a major component of tetramethrin, in buffered aqueous solutions to determine its rates and routes in the aquatic environments. HPLC analysis of buffered aqueous solution was conducted instead of extraction to avoid an artificial degradation of hydrolysates. In order to confirm the chemical structures of $\mathbf{I}$ and its degradates, LC-MS spectra were measured by using the frit- $\mathrm{FAB}^{10)}$ and atmospheric pressure ionization (APCI) ${ }^{11)}$ techniques.

\section{MATERIALS AND METHODS}

\section{Chemicals}

I, trans-chrysanthemic acid (II) and $N$ hydroxymethyl 3,4,5,6-tetrahydrophthalimide (III) were prepared in our laboratory. 3,4,5,6Tetrahydrophthalic anhydride was purchased 
from Aldrich Chemical Co., Ltd. (Milwaukee) and treated with a 1.05 equivalent of sodium hydroxide in acetonitrile-distilled water (1/1, $\mathrm{v} / \mathrm{v})$ to prepare the corresponding acid $(\mathbf{l V})$. 3,4,5,6-Tetrahydrophthalamic acid (V) was prepared by treating the anhydride with ammonium hydroxide. ${ }^{12)}$ The chemical structure of each compound was confirmed by ${ }^{1} \mathrm{H}$ NMR, IR and MS spectroscopies. The chemical purity of each compound was $>99 \%$ as determined by HPLC analysis. $\left[\right.$ Acid $\left.-{ }^{14} \mathrm{C}\right]-\mathbf{I}$ labeled at 1-position of the cyclopropyl moiety $(132 \mathrm{mCi} / \mathrm{g})$ and $\left[\mathrm{Alc}-{ }^{14} \mathrm{C}\right]-\mathbf{I}$ labeled at $1-$ and 2-positions of the 3,4,5,6-tetrahydrophthalimide moiety $(149 \mathrm{mCi} / \mathrm{g})$ were prepared in our laboratory. The radiochemical purity of each preparation was $>99 \%$ on the basis of the HPLC analysis. Chromotropic acid disodium salt from Tokyo Kasei (Tokyo) for quantification of formaldehyde, organic solvents and inorganic reagents in a special grade from Wako Pure Chemical Industries, Ltd. (Osaka) were used without further purification. Pure water with an electrical conductivity of $5.5 \times 10^{-8} \Omega^{-1} \mathrm{~cm}^{-1}$ was used for the preparation of buffer solutions. PIC-A (tetrabutylammonium phosphate) used in a mobile phase was purchased from Waters Co.,

Table 1 TLC $R f$ values and HPLC retention times of $\mathbf{I}$ and its degradates.

\begin{tabular}{|c|c|c|c|}
\hline \multirow{2}{*}{ Compound } & \multicolumn{2}{|c|}{ TLC $R f$ value $\left.^{a}\right)$} & \multirow{2}{*}{$R t(\min )^{\mathrm{b}}$} \\
\hline & A & $\mathrm{B}$ & \\
\hline I & 0.40 & 0.67 & $32.0^{\mathrm{c})}$ \\
\hline II & 0.21 & 0.58 & $21.5^{c)}$ \\
\hline III & 0.12 & 0.47 & 16.6 \\
\hline IV & 0.00 & 0.17 & 8.5 \\
\hline $\mathbf{V}$ & 0.00 & $\left.0.54,0.17^{d}\right)$ & 6.5 \\
\hline VI & -e) & - & 24.0 \\
\hline VII & - & - & 10.0 \\
\hline
\end{tabular}

a) A, hexane/ethyl acetate $(1 / 1, \mathrm{v} / \mathrm{v}) ; \mathrm{B}$, toluene/ ethyl acetate/acetic acid $(5 / 7 / 1, \mathrm{v} / \mathrm{v} / \mathrm{v})$. b) Typical retention times in HPLC analysis (Table 2). c) Retention times of the cis-isomers of $\mathbf{I}$ and II were 31.5 and $21.8 \mathrm{~min}$, respectively. d) $\mathbf{V}$ was unstable and partly degraded to IV on the TLC plate during development with the solvent system B. e) Not determined due to a rapid degradation during development.
Ltd. (Milford). The nutrient agar (mixtures of bacto-beef extract, bacto-peptone, and bacto-agar) used for examining sterility of buffered aqueous solutions was obtained from DIFCO Laboratories.

\section{2. $T L C$}

Precoated silica gel $60 \mathrm{~F}_{254}$ chromatoplates $(20 \times 20 \mathrm{~cm}, \quad 0.25 \mathrm{~mm}$ layer thickness, E. Merck) were used for an analytical purpose. The TLC $R f$ values of $\mathbf{I}-\mathbf{V}$ with the two solvent systems used in two-dimensional development are listed in Table 1 . The resolved radioactive spots were detected by autoradiography with the developed TLC plates held under X-ray SB film (Eastman Kodak Company) at $4^{\circ} \mathrm{C}$ for a week. The unlabeled standard chemicals were detected by ultraviolet light fluorescence quenching.

\section{3. $H P L C$}

A Hitachi L-6200 liquid chromatograph was operated at a flow rate of $1.0 \mathrm{ml} / \mathrm{min}$ to flush the contents of the $2 \mathrm{ml}$ loop onto a Sumipax ODS A-112 $(5 \mu \mathrm{m}, 6 \mathrm{~mm}$ i.d. $\times 15 \mathrm{~cm}$; Sumika Analytical Service Ltd., Osaka) column. The composition of mobile phase was changed stepwise as described in Table 2. The amount of $\mathbf{I}$ and its hydrolysis products were quantified, using a Radiomatic Flo-one/beta A-120 radiodetector (time constant, $6.0 \mathrm{sec}$ ) were a quantitation limit was about $500 \mathrm{cpm}$. At the same time, the UV absorbance at $240 \mathrm{~nm}$ was monitored by using a Hitachi L-4000 Variable Wavelength UV Monitor. The retention times of $\mathbf{I}-\mathbf{V}$ are listed in Table 1.

Table 2 HPLC mobile phase conditions.

\begin{tabular}{rcrrl}
\hline $\begin{array}{c}\text { Time } \\
(\min )\end{array}$ & $\begin{array}{c}\left.\mathrm{A}^{a}\right) \\
(\%)\end{array}$ & $\begin{array}{r}\left.\mathrm{B}^{\mathrm{a}}\right) \\
(\%)\end{array}$ & $\begin{array}{r}\left.\mathrm{C}^{\mathrm{a}}\right) \\
(\%)\end{array}$ & Curve \\
\hline 0 & 20 & 0 & 80 & \\
5 & 20 & 0 & 80 & Isocratic \\
15 & 70 & 20 & 10 & Linear \\
25 & 70 & 20 & 10 & Isocratic \\
30 & 20 & 0 & 80 & Linear \\
40 & 20 & 0 & 80 & Linear \\
\hline
\end{tabular}

a) Component of a mobile phase.

$\mathrm{A}$, acetonitrile; $\mathrm{B}$, methanol; $\mathrm{C}$, distilled water containing $5 \times 10^{-3} \mathrm{M}$ PIC-A. Flow rate was 1.0 $\mathrm{ml} / \mathrm{min}$ throughout analysis. 


\section{Hydrolysis Study}

The buffer solutions were prepared with the following compositions; $\mathrm{pH} 5.0,0.01 \mathrm{~m}$ acetic acid/0.01 $\mathrm{m}$ sodium acetate $(1 / 2, \mathrm{v} / \mathrm{v})$ and $\mathrm{pHs}$ 7.0 and 9.0, $0.01 \mathrm{M} \mathrm{H}_{3} \mathrm{BO}_{3}+0.01 \mathrm{M} \mathrm{KCl}$ and $0.01 \mathrm{~m} \mathrm{NaOH}$ mixed in an appropriate volumetric ratio. The buffer solution was sterilized by autoclaving at $120^{\circ} \mathrm{C}$ and 1.5 psi for an hour with a Model SS-325 autoclave (Tomy Seiko) before use. The concentration of $\mathbf{I}$ was adjusted to $0.3 \mathrm{ppm}$ below the water solubility of tetramethrin $\left(1.83 \mathrm{ppm}\right.$ at $\left.25^{\circ} \mathrm{C}\right)$. The test solution at each $\mathrm{pH}$ was duplicately prepared by adding a $1.0 \mathrm{ml}$ aliquot of acetonitrile solution of $\left[\right.$ Acid $\left.-{ }^{14} \mathrm{C}\right]-\mathbf{I}(4.16 \mu \mathrm{Ci}, 31.5 \mu \mathrm{g})$ or $\left[\right.$ Alc- $\left.{ }^{14} \mathrm{C}\right]-\mathbf{I}(4.83 \mu \mathrm{Ci}, 32.4 \mu \mathrm{g})$ to each buffer $(100 \mathrm{ml})$ in the heat-sterilized Erlenmeyer flask under continuous stirring. The flasks were kept in a Sanyo Model SHR-200M incubator at $25 \pm 1{ }^{\circ} \mathrm{C}$ in darkness for 30 days. Since I was susceptible to hydrolysis at $\mathrm{pHs} 7$ and 9, the hydrolysis study in a shorter period $(<1$ day) was separately conducted. At appropriate intervals, a $0.5 \mathrm{ml}$ aliquot of each solution was taken in duplicate and the concentration of ${ }^{14} \mathrm{C}$ was determined by using a Packard model 460CD Tri-carb scintillation spectrometer. A $1.0 \mathrm{ml}$ aliquot of the water sample was mixed with a $0.2 \mathrm{ml}$ aliquot of the acetonitrile/distilled water $(1 / 1, \mathrm{v} / \mathrm{v})$ solution containing the unlabeled standards and the mixture was directly analyzed by HPLC. Microbial contamination was avoided by conducting all procedures up to HPLC analysis aseptically in a clean bench. The sterility of the buffered aqueous solutions was checked at the beginning and end of the study by the dilution plate method, using the medium developed by Martin \& Johnson and the nutrient agar medium. ${ }^{13)} \quad$ I and II were fractionated by HPLC and separately extracted with ethyl acetate. The fractions of $\mathbf{I V}, \mathbf{V}$ and the two unstable degradates (VI and VII) were separately lyophilized. The extracted or lyophilized samples dissolved in methanol were subject to the two-dimensional TLC analysis together with the non-labeled synthetic standards in order to confirm a chemical structure of each degradate.

\section{LC-MS}

LC-MS spectra of $\mathbf{I}$ and its degradates in reaction mixtures were measured by using the following instruments: Hitachi M-1000 LC-MS equipped with an APCI interface ${ }^{11)}$ (positive ion (PI) and negative ion (NI) modes; drift voltages were $130 \mathrm{~V}$ and $-140 \mathrm{~V}$, respectively) linked with a Hitachi L-6200 Liquid Chromatograph and an Intertsil ODS-2 $(5 \mu \mathrm{m}, 4.6 \mathrm{~mm}$ i.d. $\times 25 \mathrm{~cm}$ ) column in series; JEOL JMSLX1000 LC-MS equipped with a FAB interface (Xe gas, glycerol matrix; NI mode, -3 $\mathrm{kV})$ linked with a Yokogawa LC-100 Liquid Chromatograph and a Sumipax ODS A-112 $(5 \mu \mathrm{m}, 6 \mathrm{~mm}$ i.d. $\times 15 \mathrm{~cm})$ column in series. The mobile phase was similar to that used in the hydrolysis study, but PIC-A was replaced with $0.1 \mathrm{M}$ ammonium acetate in the former LC-MS analysis. LC-MS analysis of $\mathbf{I}$ and its degradates was conducted at an exaggerated concentration. A $0.5 \mathrm{ml}$ aliquot of acetonitrile solution containing non-labeled I $(0.1 \mathrm{mg})$ was mixed well with $9.5 \mathrm{ml}$ of $0.01 \mathrm{~m}$ borate buffer $(\mathrm{pH} 9)$, resulting in $10 \mathrm{ppm}$ aqueous solution. After incubation at $25^{\circ} \mathrm{C}$ for $20 \mathrm{~min}$, a $1.0 \mathrm{ml}$ aliquot was subjected to LC-MS analysis.

\section{Quantitation of Formaldehyde}

Formaldehyde formed via hydrolysis of $\mathbf{I}$ was spectrophotometrically quantified according to the reported method by using chromotropic acid. ${ }^{14)}$ A standard response curve of formaldehyde was prepared for concentrations of between 0.5 and $5 \mu \mathrm{M}$. The buffered aqueous solution of $\mathbf{I}(0.3 \mathrm{ppm}, 0.9 \mu \mathrm{M})$ at $\mathrm{pH} 9$ was prepared similarly as in the hydrolysis study and a $1.0 \mathrm{ml}$ aliquot was subjected to analysis after incubation for an hour at $25^{\circ} \mathrm{C}$. Since acetonitrile was found to inhibit the complex formation, methanol was used as a cosolvent instead.

\section{RESULTS AND DISCUSSION}

\section{Hydrolysis Rate}

Hydrolysis of $\mathbf{I}$ at $\mathrm{pH} 5$ followed pseudofirst-order kinetics and the apparent rate constants $(k)$ in an average were calculated to be $4.99 \times 10^{-7}$ and $4.08 \times 10^{-7} \mathrm{sec}^{-1}$ for $\left[\right.$ Acid- ${ }^{14} \mathrm{C}$ ]and $\left[\right.$ Alc- $\left.{ }^{14} \mathrm{C}\right]$-labeled compounds, respectively, by the least square approximation method (correlation coefficient $(r)=-0.99$ ) on the 
basis of the amounts of $\mathbf{I}$ at $0-30$ days. In contrast, the decline curves of $\mathbf{I}$ at pHs 7 and 9 showed breaks at 2-4 days and 45-60 min, respectively. Almost the similar hydrolytic profiles have been previously reported for $\mathrm{N}$ phenyl 3,4,5,6-tetrahydrophthalimide ${ }^{15)}$ and two reactions were likely to be involved. The apparent hydrolysis rates of $\mathbf{I}$ due to the slower reaction were first estimated on the basis of the data at 3-14 days $(\mathrm{pH} 7)$ and $1-24 \mathrm{hr}(\mathrm{pH}$ 9). The average initial $k$ values at each $\mathrm{pH}$ were then calculated by subtracting its contribution from the data at $0-1$ day $(\mathrm{pH} 7)$ and $0-30 \mathrm{~min}(\mathrm{pH} 9)$ in the reported manner ${ }^{15)}$ as follows: $7.82 \times 10^{-6} \mathrm{sec}^{-1}\left(\mathrm{pH}\right.$ 7), $6.02 \times 10^{-4}$ $\sec ^{-1}\left(\mathrm{pH}\right.$ 9) for [Acid- $\left.{ }^{14} \mathrm{C}\right]-\mathbf{I} ; 8.75 \times 10^{-6} \mathrm{sec}^{-1}$ $(\mathrm{pH} 7), 8.62 \times 10^{-4} \mathrm{sec}^{-1}(\mathrm{pH} 9)$ for $\left[\mathrm{Alc}^{-14} \mathrm{C}\right]-\mathbf{I}$. The slope in the $\log k v s$. $\mathrm{pH}$ plot $^{15)}$ was 0.8 $(r=0.99)$, showing that the second-order basecatalyzed process was dominant in hydrolysis of $\mathbf{I}$. The second-order rate constant was calculated to be $3.41 \times 10^{3} \mathrm{M}^{-1} \mathrm{sec}^{-1}$ which was larger than that of tetrahydrophthalimide $\left(43.3 \mathrm{~m}^{-1} \mathrm{sec}^{-1}\right) \cdot{ }^{16)}$ The $k$ value reported for hydrolysis of $N$-phenyl 3,4,5,6-tetrahydrophthalimide $^{15)}$ was about ten times as large as that of $\mathbf{I}$ at each $\mathrm{pH}$. These differences in the $k$ value would be, at least in part, due to a substituent effect at nitrogen of the imide moiety, as previously discussed by Hargreaves et $a l .{ }^{17)}$

\section{Product Distribution}

The total recovery of ${ }^{14} \mathrm{C}$ was $96.2-101.7 \%$ during the experiment, indicating that neither the chemical and physical adsorption of radioactive compounds onto the flask and the HPLC column nor their volatilization loss was of significance. The HPLC analysis immediately after an application of ${ }^{14} \mathrm{C}$-I showed that $100.0 \%$ (pH 5), $100.0 \%(\mathrm{pH} 7)$ and $81.7-96.2 \%$ $\left(\mathrm{pH}\right.$ 9) of the applied ${ }^{14} \mathrm{C}$ were recovered as $\mathbf{I}$, indicating a rapid hydrolysis of $\mathbf{I}$ under the alkaline conditions. Dilution plate method using the two different nutrient media showed that the buffer solutions were free from microbial contamination during the experiment and therefore the degradation observed was only due to chemical hydrolysis.

The product distribution at each $\mathrm{pH}$ is summarized in Table 3 . The main degradates at $\mathrm{pH} 5$ were $\mathbf{I I}$ (from $\left[\right.$ Acid- $\left.{ }^{14} \mathrm{C}\right]-\mathbf{I}$ ) and IV (from $\left[\right.$ Alc- $\left.\left.{ }^{14} \mathrm{C}\right]-\mathbf{I}\right)$, whose amounts gradually increased to $67.1-70.6 \%$ (II) and $65.6-66.6 \%$ (IV) of the applied ${ }^{14} \mathrm{C}$ at 30 days, respectively. The unidentified degradates amounted to less than $3.8 \%$ of the applied ${ }^{14} \mathrm{C}$ throughout the experiment. At $\mathrm{pH} \mathrm{7,} \mathrm{I} \mathrm{was} \mathrm{almost} \mathrm{completely}$ hydrolyzed to II and IV during 30-days incubation. The two degradates were additionally observed except II and IV. One of them was 3,4,5,6-tetrahydrophthalamic acid (V) characteristic to $\left[\mathrm{Alc}-{ }^{14} \mathrm{C}\right]-\mathbf{I}$. It showed a maximum amount $(15.2-15.7 \%)$ at Day-1 but

Table 3 Amounts of $\mathbf{I}$ and its degradation products.

\begin{tabular}{|c|c|c|c|c|c|c|}
\hline \multirow{4}{*}{ Compound } & \multicolumn{6}{|c|}{$\%$ of the applied $\left.{ }^{14} \mathrm{C}^{\mathrm{a}}\right)$} \\
\hline & \multicolumn{2}{|c|}{ pH 5} & \multicolumn{2}{|c|}{$\mathrm{pH} 7$} & \multicolumn{2}{|c|}{ pH 9} \\
\hline & \multicolumn{2}{|c|}{14 days } & \multicolumn{2}{|c|}{1 day } & \multicolumn{2}{|c|}{$20 \min$} \\
\hline & $A c^{b)}$ & $\left.\mathrm{Alc}^{\mathrm{c}}\right)$ & $\mathrm{Ac}$ & Alc & $\mathrm{Ac}$ & $\mathrm{Alc}^{(\mathrm{d})}$ \\
\hline I & 50.9 & 58.0 & 49.3 & 47.0 & 48.9 & 34.3 \\
\hline II & 47.7 & - e) & 46.5 & - & 36.2 & - \\
\hline IV & 一 & 42.0 & - & 29.9 & - & 1.4 \\
\hline $\mathbf{V}$ & - & - & - & 15.4 & - & 20.5 \\
\hline VI & -- & - & 4.2 & 6.3 & 13.7 & 12.2 \\
\hline VII & - & - & - & - & - & 28.2 \\
\hline Others & 1.4 & $<0.1$ & $<0.1$ & 1.4 & 1.2 & 3.4 \\
\hline
\end{tabular}

a) Averaged values between the duplicate experiments. b) [Acid- $\left.{ }^{14} \mathrm{C}\right]-\mathbf{I}$. c) $\left[\mathrm{Alc}-{ }^{14} \mathrm{C}\right]-\mathbf{I}$. d) After 30-days incubation, IV $(68.1 \%)$ and $\mathbf{V}(31.9 \%)$ were only detected on the HPLC chromatogram. e) Not detected. 

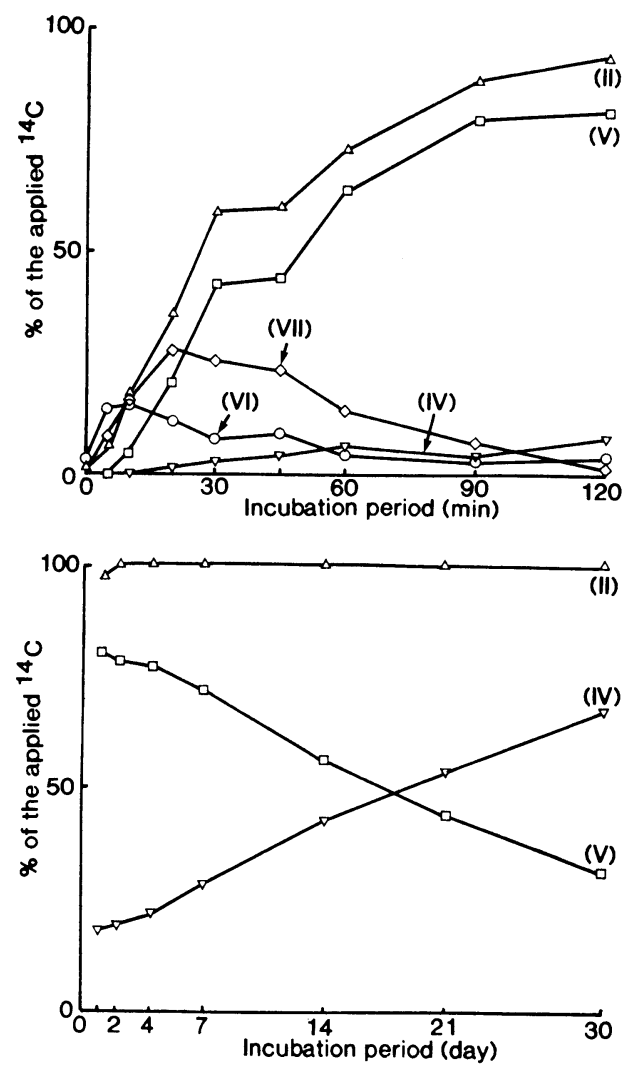

Fig. 1 Amounts of degradates in the hydrolysis of $\left[\mathrm{Alc}-{ }^{14} \mathrm{C}\right]-\mathbf{I}$ at $\mathrm{pH} 9$.

Amounts of II were from [Acid-14 C]-I.

disappeared after a week. The other degradate (VI) was transiently detected at a retention time of $c a .24$ min in HPLC with its amount of less than $7 \%$ within 4 days. Since VI was formed from both of the ${ }^{14} \mathrm{C}$ preparations of $\mathbf{I}$, it was considered that VI retained both ester and amide linkage in the molecule. The other unknown degradates amounted to less than $3.5 \%$ of the applied ${ }^{14} \mathrm{C}$. The formation and decline of hydrolysis products at $\mathrm{pH} 9$ are shown in Fig. 1. II was the main degradate from $\left[\right.$ Acid- $\left.{ }^{14} \mathrm{C}\right]-\mathbf{I} . \quad$ VI was transiently detected within $2 \mathrm{hr}$ and showed a maximum yield $(15.9-17.2 \%)$ at Min-10. In the case of [Alc$\left.{ }^{14} \mathrm{C}\right]-\mathbf{I}$, the product distribution similar to that at $\mathrm{pH} 7$ was observed except that an another degradate (VII) was detected at a retention time of $10.0 \mathrm{~min}$. Since VII was detected only with the $\left[\mathrm{Alc}-{ }^{14} \mathrm{C}\right]$ preparation, it seemed to be formed via cleavage of the ester linkage or successive hydrolysis of the imide ring. The amount of VII showed a maximum value at $20 \mathrm{~min} \quad(27.7-28.6 \%)$ but rapidly decreased thereafter. After 1 day, the main degradates were IV and V, amounting to $67.3-68.8 \%$ and $31.2-32.7 \%$ at 30 days, respectively. At any $\mathrm{pH}$ tested, III formed via cleavage of the ester linkage of $\mathbf{I}$ was not detected. Neither I nor II underwent geometrical isomerization to the corresponding cis-isomer at any $\mathrm{pH}$ tested, as clarified by HPLC analysis.

\section{Product Identification}

I, II, IV and V detected by radio-HPLC were tentatively identified by cochromatography with the corresponding non-labeled authentic standards, by comparing their retention times. The chemical identity of each compound was further confirmed by twodimensional TLC cochromatography. During the development on TLC plate, $\mathbf{V}$ was found to be partly degraded to IV. V seemed to be unstable under the acidic conditions, judging from the structural similarity to phthalamic acid which easily degrades to phthalic acid. ${ }^{18)}$ The chemical structures of $\mathbf{I}, \mathbf{I I}$ and $\mathbf{V}$ were also identified by LC-MS as follows: I, APCI (PI mode), $m / z 349\left(\mathrm{M}+\mathrm{NH}_{4}{ }^{+}\right), 332\left(\mathrm{M}+\mathrm{H}^{+}\right)$; II, frit-FAB (NI mode), $m / z \quad 259 \quad\left(\mathrm{M}-\mathrm{H}^{-}+\right.$ glycerol), $167\left(\mathrm{M}-\mathrm{H}^{-}\right)$; V APCI (PI mode), $m / z 187\left(\mathrm{M}+\mathrm{NH}_{4}{ }^{+}\right), 170\left(\mathrm{M}+\mathrm{H}^{+}\right), 153$ (acid anhydride of $\mathbf{I V}+\mathrm{H}^{+}$), API (NI mode), $m / z$ $168\left(\mathrm{M}-\mathrm{H}^{-}\right)$. The similar MS spectrum has been previously reported for I by using a thermospray technique. ${ }^{19)}$

VI and VII isolated by HPLC from the reaction mixture at $\mathrm{pH} 9$ were first subjected to the TLC analysis. However, they were found to be degraded during the TLC development. VI afforded the several unresolved spots including IV and $\mathbf{V}$ on TLC. In the case of VII, the two spots due to $\mathbf{I V}$ and $\mathbf{V}$ were detected. In order to identify the chemical structures of VI and VII, more amounts of these degradates were prepared in a separate experiment. The borate buffer $(\mathrm{pH} 9)$ containing ${ }^{14} \mathrm{C}-\mathrm{I}$ at 1.5 ppm was prepared in the presence of $5 \%$ acetonitrile and incubated for $20 \mathrm{~min}$ at $25^{\circ} \mathrm{C}$. A $2.0 \mathrm{ml}$ aliquot was analyzed by HPLC and the fractions corresponding to VI and VII were 


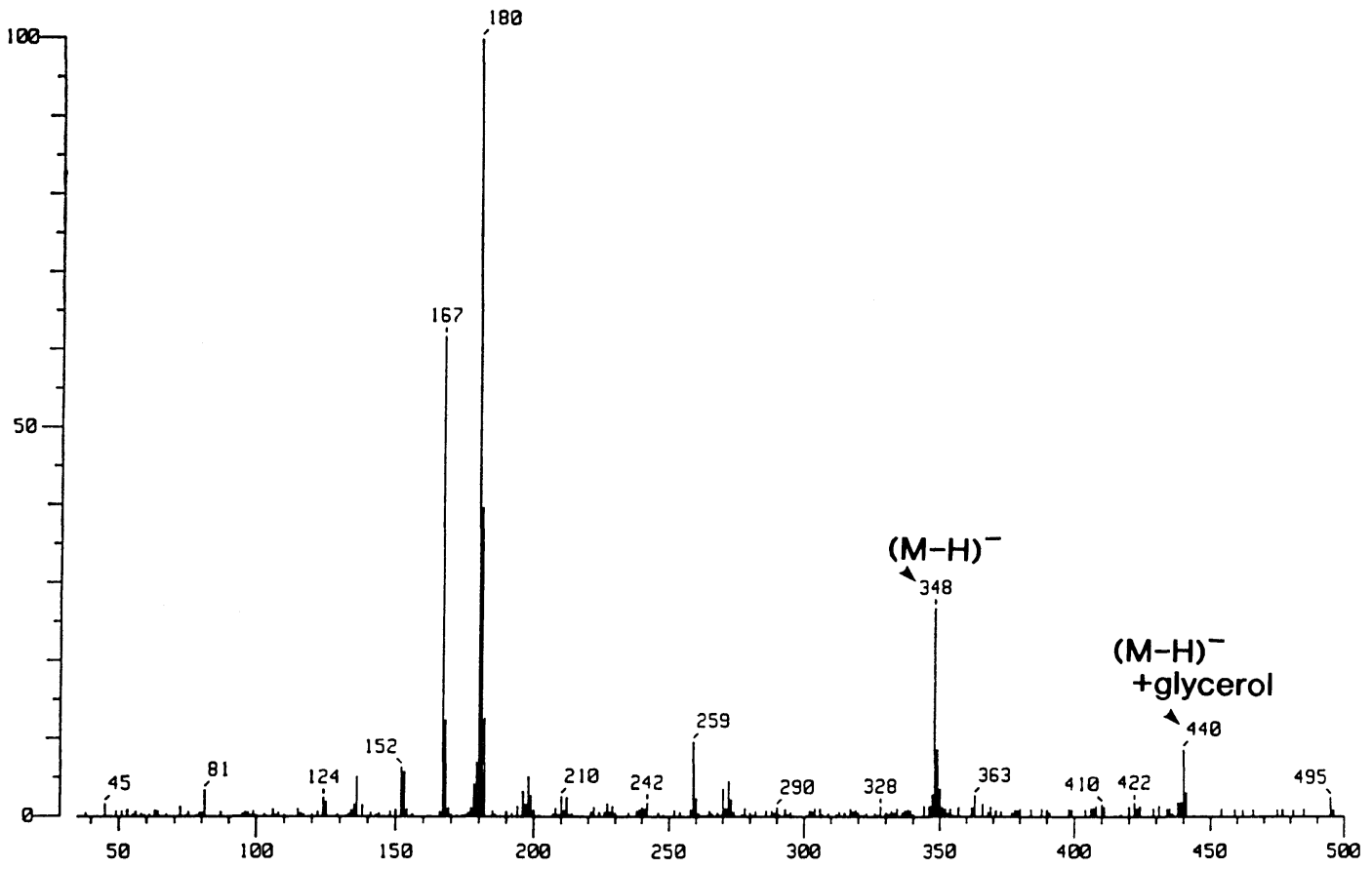

Fig. 2 LC-MS spectrum of VI by using a frit-FAB interface (negative ion mode).
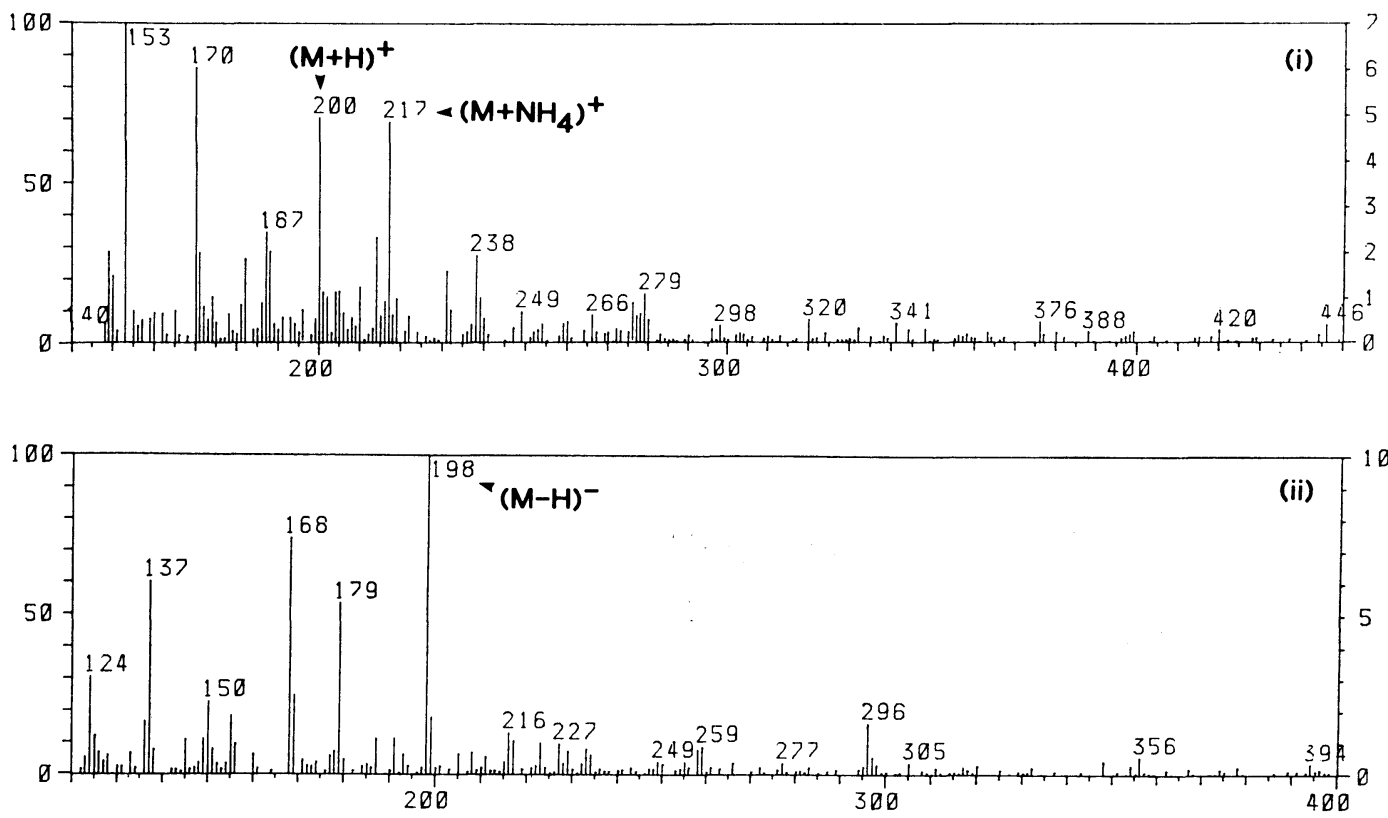

Fig. 3 LC-MS spectra of VII by using an API interface.

(i), positive ion mode; (ii), negative ion mode. 
individually collected. Since these degradates were not detected at $\mathrm{pH} 5$, they were considered to be unstable under the acidic conditions. Therefore, a $0.5 \mathrm{ml}$ aliquot of each fraction was mixed well with $0.5 \mathrm{ml}$ of $0.01 \mathrm{M}$ acetate buffer ( $\mathrm{pH} \mathrm{5.0)}$ ) and the reaction mixture was re-analyzed by HPLC after an incubation for $30 \mathrm{~min}$ at $25^{\circ} \mathrm{C}$ in order to get more structural information. HPLC re-analysis demonstrated that IV $(22.1 \%), \mathbf{V}(14.5 \%)$ and VII $(35.7 \%)$ were formed from the [Alc$\left.{ }^{14} \mathrm{C}\right]$-VI and II $(70.1 \%)$ from the $\left[\right.$ Acid- $\left.{ }^{14} \mathrm{C}\right]-\mathbf{V I}$. I $(7.1-9.8 \%)$ was also detected from both ${ }^{14} \mathrm{C}$ preparations of VI. The deviation from firstorder kinetic in the hydrolysis at $\mathrm{pHs} 7$ and 9 was likely to be due to the presence of the partial formation of I. IV $(62.1 \%)$ and $\mathbf{V}$ $(37.9 \%)$ were similarly formed from VII under the acidic conditions. Since $\mathbf{V}$ was partly degraded to IV and considered to be acidlabile by analogy of $N$-alkyl derivatives ${ }^{20)}$ and phthalamic acid, ${ }^{18)}$ it was suggested that both VI and VII had a structure of 3,4,5,6-tetrahydrophthalamic acid (V) and that VI also had II as a substructure in its molecule.

LC-MS spectrum (frit-FAB) of VI exhibited the $m / z$ value be $440\left(\mathrm{M}-\mathrm{H}^{-}+\right.$glycerol $), 348$ $\left(\mathrm{M}-\mathrm{H}^{-}\right), 180\left(\mathrm{M}-\mathrm{H}^{-}\right.$of III $)$, and $167\left(\mathrm{M}-\mathrm{H}^{-}\right.$ of II) in the NI mode (Fig. 2). In the case of VII, the $m / z$ values (APCI) detected were 217 $\left(\mathrm{M}+\mathrm{NH}_{4}{ }^{+}\right), 200\left(\mathrm{M}+\mathrm{H}^{-}\right), \quad 187\left(\mathrm{M}+\mathrm{NH}_{4}{ }^{+}\right.$of V) and $170\left(\mathrm{M}+\mathrm{H}^{+}\right.$of $\left.\mathbf{V}\right)$ in the PI mode and $198\left(\mathrm{M}-\mathrm{H}^{-}\right)$and $168\left(\mathrm{M}-\mathrm{H}^{-}\right.$of $\left.\mathbf{V}\right)$ in the NI mode (Fig. 3). LC-MS and HPLC analysis of the degradates strongly suggested that VI and VII were $N$-(1RS)-trans-chrysanthemoyloxymethyl 3,4,5,6-tetrahydrophthalamic acid formed via opening of the imide ring of $\mathbf{I}$ and $N$-hydroxymethyl -3, 4, 5, 6 - tetrahydrophthalamic acid formed via cleavage of the ester linkage of VI, respectively.

\section{Hydrolysis Pathways}

I possessed both an ester linkage and a cyclic imide moiety in its molecule and the two reaction sites feasible to hydrolysis was considered. It is unlikely that the ester linkage was primarily cleaved, since III was not detected at any $\mathrm{pH}$ tested and VI was first detected at $\mathrm{pH}$ 9 followed by formation of VII, as demonstrated in Fig. 1. Although hydrolytic profiles of pyrethroids possessing the trans-chrysanthemoyloxymethyl moiety have not been studied previously, the apparent hydrolysis rates of $(1 R)$-trans-cypermethrin and fenpropathrin at $25^{\circ} \mathrm{C}$ have been reported to be $5.6 \times 10^{-9} \mathrm{sec}^{-1}$ and $9.1 \times 10^{-9} \mathrm{sec}^{-1}(\mathrm{pH} 5), 3.7 \times 10^{-8} \mathrm{sec}^{-1}$ and $5.9 \times 10^{-8} \mathrm{sec}^{-1}(\mathrm{pH} 7)$, and $2.7 \times 10^{-6} \mathrm{sec}^{-1}$ and $5.1 \times 10^{-6} \mathrm{sec}^{-1}(\mathrm{pH} 9)$, respectively. ${ }^{21,22)}$ These values showed that the change of a substituent at 3-position of the cyclopropyl ring caused an insignificant effect on the rate of hydrolysis at the ester linkage. Since the apparent hydrolysis rate of $\mathbf{I}$ at each $\mathrm{pH}$ was about 100 times as large as these values, the faster hydrolysis seemed to be mainly due to the opening of the imide ring. The second-order rate constant of tetrahydrophthalimide in alkaline hydrolysis has been reported to be $43.3 \mathrm{~m}^{-1} \mathrm{sec}^{-1}{ }^{16}$ ) and the substitution of $N$-hydrogen with the electron-withdrawing $\mathrm{COOCH}_{2}$ moiety is expected to accelerate the opening of the imide ring. Such an alkaline reaction was known to be kinetically effective at extremely low hydroxide concentration $(\mathrm{pH} \geqq 3),{ }^{17)}$ which accounted for the large hydrolysis rate constant under the acidic conditions.

Since VI was the tetrahydrophthalamic acid derivative, an intramolecular acid-catalyzed cleavage of the amide linkage by the adjacent carboxyl group could be considered as a hydrolysis mechanism besides the cleavage of the ester linkage. This type of reaction has been extensively studied for various amic acids. ${ }^{20,23)}$ The anhydride of $\mathbf{I V}$ is unstable in the aqueous media ${ }^{24}$ and therefore aminomethyl trans-chrysanthemate and IV should be formed as products via this catalytic reaction mechanism, while II and VII, and/or V due to an instability of VII, were the products via the cleavage of the ester linkage. At $\mathrm{pH} \mathrm{5}$, any kind of degradate characteristic to $\left[\right.$ Acid- $\left.{ }^{14} \mathrm{C}\right]$ preparation was not detected except II and IV was only detected in the hydrolysis of [Alc$\left.{ }^{14} \mathrm{C}\right]$-I. Since both aminomethyl trans-chrysanthemate and VII were considered to be very unstable judging from their chemical structures (hemiaminal derivatives) and $\mathbf{V}$ was also unstable under the acidic conditions, it was difficult to determine which mechanism was favored. The acid-catalyzed ester cleavage was considered to be much slower than 
the base-catalyzed process as reported for pyethroids $^{21,22)}$ and the intramolecular catalytic cleavage of the amide linkage was an extremely rapid process. Supposing that the hydrolytic profile of the ester linkage in $\mathbf{I}$ is almost the same as those of trans-cypermethrin and fenpropathrin, the acid-catalyzed intramolecular reaction might be most probable in the degradation of VI.

In contrast with the amide cleavage, the ester cleavage of VI was considered to become dominant at $\mathrm{pH} 7$ and 9 . The product distribution was in good agreement with that predicted from the ester cleavage mechanism. Although VII was not detected at $\mathrm{pH} 7$ at any sampling time, it might be due to its instability even at $\mathrm{pH}$ 7. Furthermore, it is known that the intramolecular catalysis becomes insignificant under the neutral and alkaline conditions, ${ }^{15)}$ which also suggests the ester cleavage pathway. The partial recyclization of VI to $\mathbf{I}$ was considered to proceed via nucleophilic attack of the amide nitrogen at the adjacent carboxyl carbon similarly as reported for $N$ methylphthalamic acid. ${ }^{25)}$ Meanwhile, the spectrophotometric method using a chromotropic acid showed the quantitative formation of formaldehyde $(0.9-1.0 \mu \mathrm{M})$ from I $(0.3 \mathrm{ppm}$, $0.9 \mu \mathrm{M})$ at $\mathrm{pH} 9$. Since VII was a transient species showing a maximum amount at $20 \mathrm{~min}$ and $\mathrm{pH} 9$ and decreased afterwards with a concomitant increase of $\mathbf{V}$ (Fig. 1), it was con-

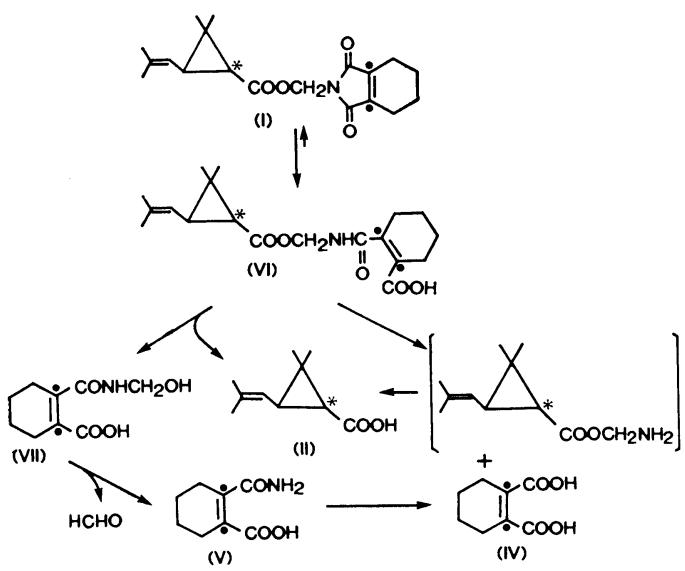

Fig. 4 Hydrolysis pathways of $\mathbf{I}$. *,,${ }^{14} \mathrm{C}$-labeled positions. sidered that formaldehyde was liberated from VII.

On the basis of these results, the hydrolysis pathways are proposed in Fig. 4. I was hydrolyzed to VI, which was subsequently degraded to VII and II and partly reverted to I. By liberating formaldehyde, VII was further degraded to $\mathbf{V}$ followed by its degradation to IV. Although the hydrolysis rate and route were dependent on $\mathrm{pH}$ tested, I was found to finally degrade to II and IV.

\section{REFERENCES}

1) G. Shinjo, T. Yamaguchi, S. Tsuda, K. Yoshida \& Y. Okuno: Jpn.J. Sanit. Zool. 32, 221 (1981)

2) T. Kato, K. Ueda \& K. Fujimoto: Agric. Biol. Chem. 28, 914 (1964)

3) H. Kaneko, H. Ohkawa \& J. Miyamoto: $J$. Pesticide Sci. 6, 425 (1981)

4) I. H. Smith \& J. E. Casida: Tetrahedron Lett. 22, 203 (1981)

5) I. H. Smith, E. J. Wood \& J. E. Casida: J. Agric. Food Chem. 30, 598 (1982)

6) J. P. Leahey: "The Pyrethroid Insecticides," ed. by J. P. Leahey, Taylor \& Francis, London, pp. 263-342, 1985

7) Y.-L. Chen \& J. E. Casida: J. Agric. Food Chem. 17, 208 (1969)

8) L. O. Ruzo, I. H. Smith \& J. E. Casida: J. Agric. Food Chem. 30, 110 (1982)

9) F. E. Rickett: Analyst 98, 687 (1973)

10) Y. Ito, T. Takeuchi \& D. Ishii: J. Chromatogr. 346, 161 (1985)

11) M. Sakairi \& H. Kambara: Anal. Chem. 60. 774 (1988)

12) E. Chapman \& H. Stephen: J. Chem. Soc. 1925, 1791

13) C. H. Collins \& P. M. Lyne: "Microbiological Methods," Butterworth \& Co., Ltd. and University Park Press, London, pp. 113-153, 1970

14) A. P. Altshuller, D. L. Miller \& S. F. Sleva: Anal. Chem. 33, 621 (1961)

15) T. Katagi: J. Pesticide Sci. 14, 497 (1989)

16) W. Hückel \& H. Müller: Chem. Ber. 64B, 1981 (1931)

17) M. K. Hargreaves, J. G. Pritchard \& H. R. Dave: Chem. Rev. 70, 439 (1970)

18) M. L. Bender, Y.-L. Chow \& F. Chloupek: J. Am. Chem. Soc. 80, 5380 (1958)

19) D. Barcelo: LC-GC 6, 324 (1988)

20) M. F. Aldersley, A. J. Kirby, P. W. Lancaster' R. S. McDonald \& C. R. Smith: J. Chem. Soc. Perkin Trans. II 1974, 1487

21) N. Takahashi, N. Mikami, T. Matsuda \& J 
Miyamoto: J. Pesticide Sci. 10, 643 (1985)

22) N. Takahashi, N. Mikami, H. Yamada \& J. Miyamoto: Pestic. Sci. 16, 113 (1985)

23) A. J. Kirby \& P. W. Lancaster: J. Chem. Soc. Perkin Trans. II 1972, 1206

24) L. Eberson: Acta Chem. Scand. 18, 1276 (1972)

25) J. Brown, S. C. K. Su \& J. A. Shafer: J. Am. Chem. Soc. 88, 4468 (1966)

要 約

\section{trans-Tetramethrin の加水分解}

片木敏行

$\left[{ }^{14} \mathrm{C}\right]$ trans-tetramethrin $(\mathbf{I})$ の $25 \pm 1^{\circ} \mathrm{C}$ での加水分
解速度は HPLC 分析により， $4.08 \sim 4.99 \times 10^{-7} \mathrm{sec}^{-1}$

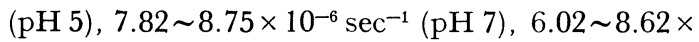
$10^{-4} \mathrm{sec}^{-1}(\mathrm{pH}$ ) と求められ, 塩基触媒的に分解する ことがわかった. HPLC, 2D-TLC, LC-MS (APCI \& Frit-FAB, 正負イオンモード) 分析により I は, イミド 環の開裂により水中で不安定な I のアミド酸を生成し, さらにエステル結合の開裂により trans-菊酸とアルコ ール部分由来の水中で不安定なアミド酸に分解すること がわかった.アルコール部分はクロモトロピック酸を用 いた吸光法により，ホルムアルデヒドと $3,4,5,6$-テト ラヒドロフタルアミド酸に分解し, 最終的には対応する ジカルボン酸にをで分解することが明らかとなった。 